\title{
Host suitability of two biotypes of Bemisia tabaci on some common weeds
}

\author{
M. Muñiz \\ Departamento de Protección Vegetal, Centro de Ciencias Medioambientales (CSIC), c/ Serrano 115 Dpdo., \\ 28006 Madrid, Spain (Fax: 349156408 00; E-mail: mmuniz@ccma.csic.es)
}

Accepted: January 4, 2000

Key words: Bemisia tabaci, Hemiptera, Aleyrodidae, Biotype B, Biotype Q, weed hosts, reproduction, development

\begin{abstract}
Significant differences in some reproductive parameters of the B and Q biotypes of Bemisia tabaci (Gennadius) with regard to four species of winter weeds were determined in a no-choice assay. The highest fecundity (eggs) and fertility (pupae and adults) were obtained with Malva parviflora L. as host, followed by Capsella bursa-pastoris L., Brassica kaber (DC) and Lactuca serriola L. The percentage of adult emergence (from egg to adult) was significantly higher $(\mathrm{P}<0.001)$ with M. parviflora, C. bursa-pastoris and B. kaber than with L. serriola. Except on $L$. serriola, the mean values of the reproductive parameters for the Q-biotype were significantly $(\mathrm{P}<0.05)$ greater than those for the B-biotype. On the other hand, in choice experiments with summer weeds, both B- and Q-biotypes preferred Datura stramonium L. and Solanum nigrum L. to Amaranthus retroflexus L., Chenopodium album L. and Echinochloa crus-galli L. Significantly more males and females, and more pupae and empty pupal cases per plant were found on D. stramonium than on S. nigrum. Adult abundance on A. retroflexus, C. album and E. crus-galli plants was very low. At a constant temperature of $26 \pm 1{ }^{\circ} \mathrm{C}$, the Q-biotype developed significantly faster than the B-biotype on $S$. nigrum and D. stramonium. Both biotypes required, for this development, significantly more days on $D$. stramonium than on S. nigrum. These results suggest that it is important to suppress the growth of M. parviflora, C. bursa-pastoris, B. kaber, D. stramonium and S. nigrum in order to avoid the risk of further expansion of whitefly populations where these weeds and both B- an Q-biotypes are present.
\end{abstract}

\section{Introduction}

Bemisia tabaci (Gennadius) has become a major pest, causing serious losses to many crops (Brown, 1990, 1994; Perring et al., 1993). It has been recorded in Spain since 1945 (Gómez-Menor, 1943), where it has caused important damage to horticultural crops in various areas (Carnero et al., 1990). Damage is caused primarily by phloem feeding of immature and adults on crop foliage or indirectly by transmitting at least 50 types of geminiviruses to a wide range of vegetable and fibre crops in tropical and subtropical temperature zones (Bedford et al., 1994a, b; Bird \& Maramorosch, 1978; Brown, 1994; Brown \& Bird, 1992, 1996; Byrne et al., 1990; Markham et al., 1994). The tomato yellow leaf curl virus (TYLCV) was reported for the first time in Spain in 1992 (Moriones et al., 1993) and has a serious impact on many horticultural crops.
In addition, sooty moulds which grow on honeydew deposition can lower the quality of many products (Byrne et al., 1990).

Behavioural diversity within a population of insects is common, and variation may occur at different points in the behavioural sequences that influence host selection (Bethke et al., 1991; Bernays \& Chapman, 1994). When several biotypes and hosts of a certain pest insect species in a geographical region are present, it is important to compare their biology to understand better their economic impact. From studies involving observation of the squash silverleaf reaction, analysis of esterase patterns and the application of RAPD-PCR techniques, Guirao et al. (1997) were able to show that Spanish populations of $B$. tabaci are composed of two genetic types: B- and 'non B'biotype. The latter was recently renamed biotype Q (Rosell et al., 1997), based on the diagnosis of esterase 
electromorphs in polyacrylamide gels. Although the host list for these biotypes has not been fully developed, B. tabaci is reported to have over 500 hosts in 74 families, including numerous economically significant horticultural and ornamental species (Perring et al., 1993; Bellows et al., 1994). As summer and winter weeds could serve as potential reservoirs for whiteflies, besides protected crops (Avidov, 1956; Gerling, 1984), identification of host sequences as well as studies of population developmental rates on various hosts are important tools in achieving effective regional whitefly management (Zalom et al., 1995).

Although many studies have been carried out on the biology of the various biotypes of $B$. tabaci, especially of the A- and the B-biotypes on several host plants (see review by Drost et al., 1998), little work has been done on the Q-biotype (Muñiz \& Nombela, 1997a, b). However, the latter recently became more numerous than the B-biotype in several horticultural crops, such as tomato, pepper, lettuce and melon in southern Spain (F. Beitia, pers. comm.) where the weed species of this study are very common (Villarias, 1979). The aim of this study was to increase knowledge about host preference and suitability of both B- and Qbiotypes of $B$. tabaci with regard to a number of common weeds so that effective management strategies can be developed in those places where these weeds and whiteflies are present. I, therefore, characterized their ability to infest these weeds and their reproductive activity on them (female oviposition, pupal and adult production, and adult emergence).

\section{Material and methods}

Reproduction of $\mathrm{B}$. tabaci biotypes on winter weeds (No-choice assay). Seeds of four winter weeds [Malva parviflora L., Capsella bursa-pastoris L., Brassica kaber (DC) and Lactuca serriola L.] were collected from an open field in Arganda (Madrid, Spain), hand-cleaned and stored dry at room temperature. One-hundred one-year-old seeds of each weed species were germinated in $9 \mathrm{~cm}$ Petri dishes (10 replicates per weed species) on one layer of Whatman No. 1 filter paper moistened with $2 \mathrm{ml}$ of distilled water. Weed plants were grown in $12 \mathrm{~cm}$ plastic pots in a standard soil mix and placed in a greenhouse at $25^{\circ} \mathrm{C}: 15^{\circ} \mathrm{C}$ (Light:Dark) and $70-78 \%$ r.h. Adult whiteflies were collected with aspirators from two large stock colonies (Biotypes B and Q) reared on poinsettia plants (Euphorbia pulcherrima Willd. ex
Klotzsch) for 20 generations in two greenhouses at between $16^{\circ} \mathrm{C}$ and $28^{\circ} \mathrm{C}$ with $65-75 \%$ r.h. Greenhouses were separated and totally isolated by glass walls and anti-thrips gauze in the windows to ensure that there was no cross contamination. At 60 days old, the plants were artificially infested with adult $B$. tabaci females in clear plastic clip-cages $(3.6 \mathrm{~cm}$ maximum diameter; $2.6 \mathrm{~cm}$ minimum diameter; $4 \mathrm{~cm}$ high) (Muñiz \& Nombela, 1997a) which were attached to the leaves and held in a PGV 36 Conviron chamber at the Centro de Ciencias Medioambientales (Madrid, Spain). One 7-day-old female of each biotype was introduced into each of 120 clip-cages (one cage per plant; 24 plants per weed species). Conditions in the climatic chamber were maintained at $25^{\circ} \mathrm{C}: 15^{\circ} \mathrm{C}$ (L:D), a photoperiod of L14:D10 h. and 65-70\% r.h. Whiteflies were allowed to oviposit over a 3-day period, after which they were removed. The plants were then transported to the laboratory, where the outline of the cages was marked, and the marked area examined using a binocular dissecting microscope to record the number of eggs laid. The plants were subsequently moved to the climatic chamber and the clip-cages were replaced to exclude potential oviposition by female whiteflies. After 20 and 30 days, the number of pupae and empty pupal cases (representing emerged adults), respectively, were recorded.

Host preference of $\mathrm{B}$. tabaci biotypes on summer weeds (Choice assay). Seeds of five summer weeds (Amaranthus retroflexus L., Chenopodium album L., Datura stramonium L., Echinochloa crus-galli L. and Solanum nigum, L.) were collected from an open field at La Poveda Experimental Station (Madrid, Spain) hand-cleaned and stored dry at room temperature in the Centro de Ciencias Medioambientales. One-hundred one-year-old seeds of each species were germinated in $9 \mathrm{~cm}$ sealed Petri dishes on a layer of Whatman No. 1 filter paper moistened with $2 \mathrm{ml}$ distilled water. Weed plants were grown in $12 \mathrm{~cm}$ plastic pots in a standard soil mix and placed in a growing chamber at $26^{\circ} \mathrm{C}: 18^{\circ} \mathrm{C}$ (L:D), L16:D8 h. When the potted plants were 60 days old, they were moved to two isolated, empty greenhouses and randomized in a complete block design with 20 replicates per weed species. Each plant was equidistant from the adjacent pot so that their leaves did not touch each other. Three days after moving the plants to the greenhouse, approximately 1000 individuals of each whitefly biotype were released separately in each of two greenhouses similar to those in the previous ex- 
periment. At that time, the sex ratios (male/female) for B- and Q-biotypes were determined by observing the adults under a stereomicroscope, removing 100 of them from each of the greenhouses. The mean $( \pm S E)$ sex ratio values were $0.96 \pm 0.11$ and $1.04 \pm 0.08$ for the B- and Q-biotypes, respectively. The whiteflies were then returned to the greenhouses. Calvetti \& Remotti (1998) reported that $72 \mathrm{~h}$ was the minimum interval from the insect release until the first recording of data to obtain reliable information on the host selection of the whiteflies, in our experiments this initial period was extended to 7 days to allow a free distribution of the insects in the greenhouses. The number of males and females was subsequently counted daily insitu on all leaves of all plants until the new adults emerged. As the larger size of females can be discerned with the naked eye, the sex ratio could be determined daily. Counts were done early in the morning before the adults began to fly. Three days after the emergence of new adults, the total number of pupae and empty pupal cases on all leaves of all plants was recorded. Greenhouse conditions were on average: temperature $22.05 \pm 0.17^{\circ} \mathrm{C}, 73.28 \pm 0.90 \%$ r.h. for B-biotype; $22.35 \pm 0.22^{\circ} \mathrm{C}, 75.56 \pm 1.22 \%$ r.h. for Q-biotype.

Development times of $\mathrm{B}$. tabaci biotypes. Following the methodology of Wang \& Tsai (1996), ten 7-dayold females of each biotype were removed from the stock colony and placed in each of 10 clip-cages (one cage per plant; five plants per weed species) attached to the under surface of the leaves. The caged females were held in a climatic chamber at $26 \pm 1{ }^{\circ} \mathrm{C}, 70-75 \%$ r.h. and L16:D8 photoperiod for a 4-h oviposition period, and then removed. Following eclosion and after the crawlers had settled down on the leaf surface, each location of the first instar was marked and numbered with a felt tip pen. As the survivorship of all immature stages was not recorded, 30 eggs for D. stramonium and 33 eggs for $S$. nigrum (which completed the development to adult) from the total number of eggs on the abaxial surface of the leaf were considered in this study; the remaining immatures were removed under a binocular microscope. As average temperature in the most important Spanish horticultural areas is around $26^{\circ} \mathrm{C}$ at the time these summer weeds are present, I selected this temperature to determine the developmental periods of immature stages of both B-and Q-biotypes of B. tabaci on D. stramonium and S. nigrum, which were their preferred weed hosts in this study.
A comparative study between biotypes was also carried out as the initial insect populations were similar to each other and environmental conditions were not significantly different.

Data were $\log _{10}(x+1)$ transformed and analysed by 2-way ANOVA and Tukey's HSD test. Percentages $(p)$ were transformed to arcsine $(p / 100)^{0.5}$ before analysis (StatSoft, 1994).

\section{Results}

Reproduction of $\mathrm{B}$. tabaci biotypes on winter weeds. For the B-biotype, fecundity, in terms of mean number of eggs laid per female, was significantly greater $(\mathrm{P}<0.001)$ on $M$. parviflora than on the other plant species. On B. kaber it was $50 \%$ that on $M$. parviflora and oviposition on L. serriola was $50 \%$ that on B. kaber. The mean number of pupae was also significantly greater $(\mathrm{P}<0.001)$ on $M$. parviflora, followed by $C$. bursa-pastoris, B. kaber and $L$. serriola. Similar results were obtained with respect to the production of adults. Percentages of adult emergence ranged from $76 \%$ on Malva to $26 \%$ on Lactuca. Mean values of these parameters were significantly greater for the Q-biotype (Table 1).

Host preference and development of $\mathrm{B}$. tabaci biotypes on summer weeds. The average daily percentage of plants infested with $B$. tabaci and the percentage of adults per day on each plant varied with weed species. For the B-biotype, one week after infestation, the largest number of males and females per plant was observed on $S$. nigrum, followed by $D$. stramonium. No adults were observed on A. retroflexus, $C$. album or E. crus-galli for the duration of the experiment (28 days) in accordance with the findings of Calvetti \& Remotti (1998), who also reported no adults on A. retroflexus $72 \mathrm{~h}$ after initial release in a choice assay. The mean percentage of plants infested with females per day and mean percentage of plants infested with total male and female adults per day was much higher for $D$. stramonium and $S$. nigrum than for the other species. The mean percentages of females and the mean percentages of total adults per day (referring to total number of females or adults) were also significantly greater $(\mathrm{P}<0.001)$ on $D$. stramonium and $S$. nigrum than on the other species. For the Qbiotype, the daily percentage of plants infested with adults and percentage of adults per day, were similar to those from the B-biotype, but mean values were 
Table 1. B. tabaci (Biotypes B and Q) eggs, pupae, adults and percentage of adult emergence on various winter weed species (Mean $\pm \mathrm{SEM} ; n=24)$

\begin{tabular}{|c|c|c|c|c|c|}
\hline \multirow{2}{*}{$\begin{array}{l}\text { B. tabaci on } \\
\text { weed species }\end{array}$} & \multicolumn{2}{|c|}{ Eggs per female } & \multirow{2}{*}{$\begin{array}{l}\text { Pupae } \\
\text { per female }\end{array}$} & \multirow{2}{*}{$\begin{array}{l}\text { Adults } \\
\text { per female }\end{array}$} & \multirow[t]{2}{*}{ Adult emergence $(\%)$} \\
\hline & Total (3 days) & Per day & & & \\
\hline \multicolumn{6}{|l|}{ B-biotype on } \\
\hline M. parviflora & $25.13 \pm 0.62 \mathrm{a} \mathrm{A}$ & $8.38 \pm 0.21 \mathrm{a} \mathrm{A}$ & $21.33 \pm 0.51 \mathrm{a} \mathrm{A}$ & $18.96 \pm 0.47 \mathrm{a} \mathrm{A}$ & $75.67 \pm 1.16 \mathrm{a} \mathrm{A}$ \\
\hline C. bursa-pastoris & $15.63 \pm 0.30 \mathrm{~b} \mathrm{~A}$ & $5.21 \pm 0.10 \mathrm{~b} \mathrm{~A}$ & $11.75 \pm 0.37 \mathrm{~b} \mathrm{~A}$ & $9.92 \pm 0.29 \mathrm{~b} \mathrm{~A}$ & $63.59 \pm 1.60 \mathrm{~b} \mathrm{~A}$ \\
\hline B. kaber & $12.41 \pm 0.34 \mathrm{c} \mathrm{A}$ & $4.14 \pm 0.11 \mathrm{c} \mathrm{A}$ & $5.38 \pm 0.27$ c A & $4.13 \pm 0.18 \mathrm{c} \mathrm{A}$ & $34.75 \pm 1.81 \mathrm{c} \mathrm{A}$ \\
\hline L. serriola & $6.04 \pm 0.24 \mathrm{~d} \mathrm{~A}$ & $2.01 \pm 0.08 \mathrm{dA}$ & $2.87 \pm 0.28 \mathrm{~d} \mathrm{~A}$ & $1.58 \pm 0.12 \mathrm{dA}$ & $26.45 \pm 1.96 \mathrm{~d} \mathrm{~A}$ \\
\hline \multicolumn{6}{|l|}{$Q$-biotype on } \\
\hline M. parviflora & $27.34 \pm 0.85$ a B & $9.11 \pm 0.28 \mathrm{a} \mathrm{B}$ & $21.98 \pm 0.49 \mathrm{a} \mathrm{A}$ & $23.87 \pm 0.66 \mathrm{a} \mathrm{B}$ & $86.98 \pm 1.89$ a B \\
\hline C. bursa-pastoris & $19.44 \pm 0.75 \mathrm{~b} \mathrm{~B}$ & $6.48 \pm 0.25 \mathrm{~b} \mathrm{~B}$ & $16.30 \pm 0.51 \mathrm{~b} \mathrm{~B}$ & $11.08 \pm 0.79 \mathrm{~b} \mathrm{~B}$ & $57.00 \pm 0.93 \mathrm{~b} \mathrm{~B}$ \\
\hline B. kaber & $10.62 \pm 0.42 \mathrm{c} \mathrm{B}$ & $3.54 \pm 0.08$ c B & $6.09 \pm 0.31 \mathrm{c} \mathrm{B}$ & $4.78 \pm 0.22 \mathrm{c} \mathrm{B}$ & $45.32 \pm 1.47 \mathrm{c} \mathrm{B}$ \\
\hline L. serriola & $3.97 \pm 0.31 \mathrm{~d} \mathrm{~B}$ & $1.32 \pm 0.11 \mathrm{~d} \mathrm{~B}$ & $2.16 \pm 0.21 \mathrm{~d} \mathrm{~B}$ & $1.14 \pm 0.09 \mathrm{~d} \mathrm{~B}$ & $28.94 \pm 2.17 \mathrm{~d} \mathrm{~A}$ \\
\hline
\end{tabular}

Means within columns followed by the same letter (in lower case among plants for each biotype; in capitals between biotypes for each plant) do not differ significantly $(\mathrm{P}<0.001)$ by Tukey's test following arcsine transformation for proportions.

higher. The sex ratio (male/female) was close to 0.5 for both biotypes, indicating that male mortality was greater than that of females (Table 2). For both, B- and Q-biotypes, the mean percentages of leaves infested with pupae and mean number of pupae per plant and pupae per leaf per plant, including empty pupal cases, were significantly $(\mathrm{P}<0.001)$ greater on $D$. stramonium than on $S$. nigrum and A. retroflexus. No pupae and empty pupal cases were observed on C. album and E. crus-galli plants . The duration of the biological cycle (egg-adult) of the Q-biotype on $D$. stramonium and $S$. nigrum was 22 days, whereas the B-biotype required 28 days to complete the full development (Table 2).

In general, development of immature stages (on average) of the Q-biotype was significantly shorter than for the B-biotype. For both, B- and Q-biotypes, the egg stage developed significantly faster $(\mathrm{P}<0.05)$ on $S$. nigrum than on D. stramonium. The number of days required for the Q-biotype to complete development from egg to adult was 20 on S. nigrum and 22 on $D$. stramonium, whereas the B-biotype required 22 days on $S$. nigrum and 23 days on $D$. stramonium (Table 3).

\section{Discussion}

Studies focused on the biology of insects that damage crops, including the accurate determination of their development and reproductive parameters on a certain host, are important to further scientific knowledge of these pests in general and for a better understand- ing of their population dynamics in particular. As polyphagous parasitoids attack a variety of insects with different host suitability, host selection is a critical element in biological control (Hågvar \& Hofsvang, 1991).

Most literature concerning economically important insects presents detailed investigations of the summer stages of their life cycle. It is clearly necessary to know that the size of the insect populations entering the overwintering stages plays a major part in determining the population levels that will be encountered in the following spring and summer (Leather et al., 1993).

Overwintering hosts of $B$. tabaci have been identified in many parts of the world (e.g., Gerling, 1983, 1984; Fattah et al., 1984; Coudriet et al., 1986; Ozgur et al., 1989). Our results with winter weeds corroborate those of Gerling (1967), who pointed out that all developmental stages of $B$. tabaci were found on Malva parviflora. They also are in accordance with Byrne \& Draeger (1989) and Watson et al. (1992), who found that lettuce was not a good host for B. tabaci. However, assuming that a short development time on a certain plant is an indication of good host suitability, our results with $L$. serriola (the worst host) contrast with those obtained by Coudriet et al. (1986), who recorded the minimum development time for $B$. tabaci on this plant. Despite observing some adults on this plant, I do not consider L. serriola a suitable host for whitefly reproduction because of the low production of eggs, pupae and adults.

As regards summer weeds, the most suitable hosts for the B- and Q-biotypes of B. tabaci in terms of 


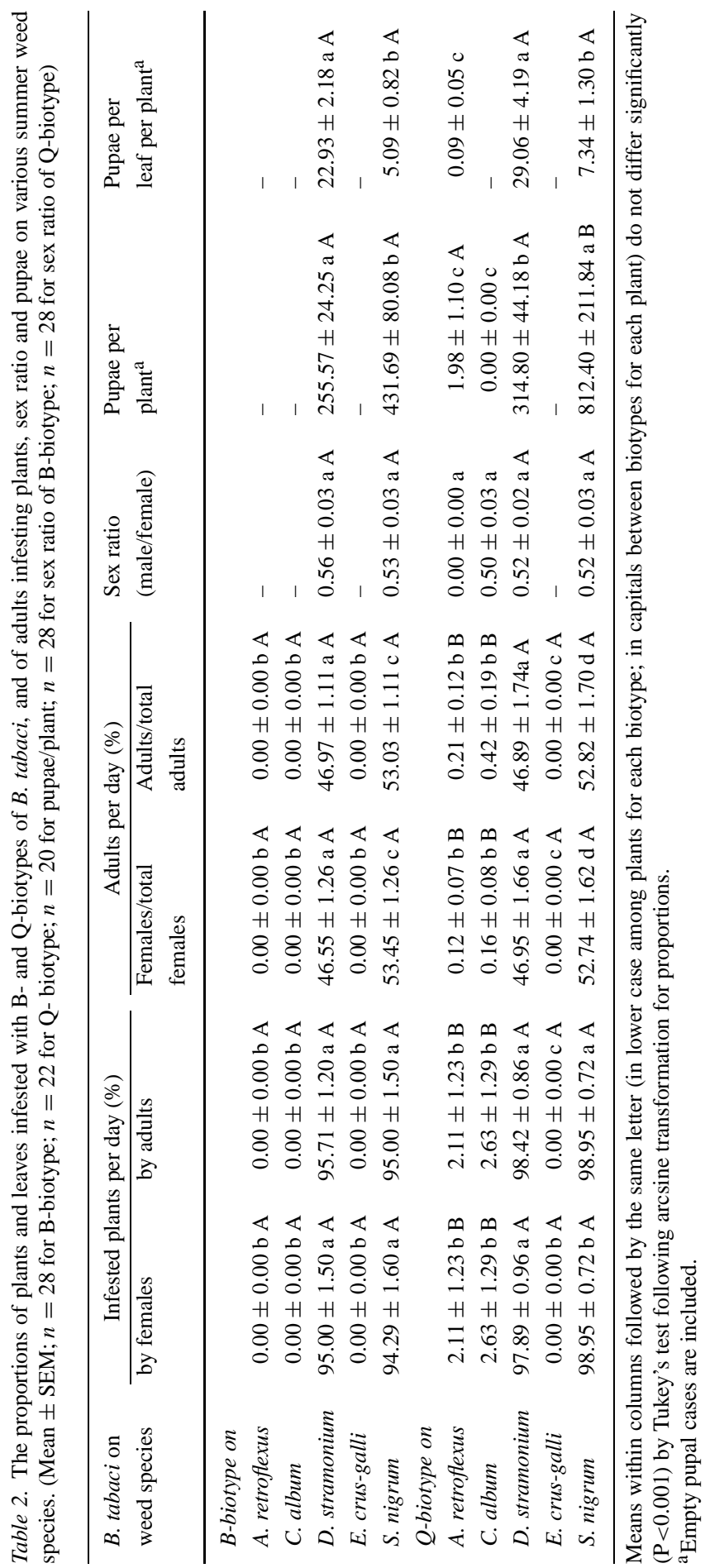


Table 3. Development times for the different $B$. tabaci instars on various weed hosts at $26^{\circ} \mathrm{C}$. (Mean \pm SEM; $n=30$ for $D$. stramonium; $n=33$ for S. nigrum)

\begin{tabular}{|c|c|c|c|c|c|c|c|}
\hline \multirow{2}{*}{$\begin{array}{l}\text { B. tabaci on } \\
\text { weed species }\end{array}$} & \multicolumn{6}{|c|}{ Life stages } & \multirow[t]{2}{*}{ From egg to adult } \\
\hline & $\overline{\text { Egg }}$ & 1st instar & 2nd instar & 3rd instar & 4th instar & Nymph & \\
\hline \multicolumn{8}{|l|}{ B-biotype } \\
\hline S. nigrum & $7.05 \pm 0.12 \mathrm{~b} \mathrm{~A}$ & $3.15 \pm 0.17 \mathrm{a} \mathrm{A}$ & $2.76 \pm 0.14 \mathrm{a} \mathrm{A}$ & $3.89 \pm 0.19 \mathrm{~b} \mathrm{~A}$ & $4.90 \pm 0.26 \mathrm{a} \mathrm{A}$ & $14.70 \pm 0.19 \mathrm{a} \mathrm{A}$ & $21.75 \pm 0.18 \mathrm{~b} \mathrm{~A}$ \\
\hline $\begin{array}{l}\text { D. stramonium } \\
\text { Q-biotype }\end{array}$ & $8.78 \pm 0.14$ a A & $3.27 \pm 0.15 \mathrm{a} \mathrm{A}$ & $2.12 \pm 0.12 \mathrm{~b} \mathrm{~A}$ & $4.08 \pm 0.13 \mathrm{a} \mathrm{A}$ & $5.18 \pm 0.30 \mathrm{a} \mathrm{A}$ & $14.65 \pm 0.18 \mathrm{a} \mathrm{A}$ & $23.43 \pm 0.16 \mathrm{a} \mathrm{A}$ \\
\hline S. nigrum & $6.34 \pm 0.16 \mathrm{~b} \mathrm{~B}$ & $2.76 \pm 0.12 \mathrm{a} \mathrm{A}$ & $2.21 \pm 0.12 \mathrm{a} \mathrm{B}$ & $4.12 \pm 0.23 \mathrm{a} \mathrm{A}$ & $4.82 \pm 0.20 \mathrm{a} \mathrm{A}$ & $13.91 \pm 0.17$ a B & $20.24 \pm 0.19 \mathrm{~b} \mathrm{~B}$ \\
\hline D. stramonium & $8.54 \pm 0.12 \mathrm{a} \mathrm{A}$ & $2.77 \pm 0.12 \mathrm{a} \mathrm{B}$ & $1.77 \pm 0.09 \mathrm{~b} \mathrm{~B}$ & $4.53 \pm 0.18 \mathrm{a} \mathrm{B}$ & $4.30 \pm 0.15 \mathrm{a} \mathrm{B}$ & $13.43 \pm 0.21 \mathrm{~b} \mathrm{~B}$ & $21.90 \pm 0.22 \mathrm{a} \mathrm{B}$ \\
\hline
\end{tabular}

Means within columns followed by the same letter (in lower case among plants for each biotype; in capitals between biotypes for each plant) do not differ significantly $(\mathrm{P}<0.001)$ by Tukey's test.

number of infested plants, adult numbers and pupal production were $D$. stramonium and $S$. nigrum. The Qbiotype showed a higher level of infestation by adults and a shorter reproductive period on these plants than did the B-biotype, which supports the evidence of reproductive variation in Bemisia biotypes (Muñiz \& Nombela, 1997a). However, adult and pupal abundance and sex ratio of B- and Q-biotype were similar. This study agrees with the work of Gameel (1972), who found that these weeds may be alternative hosts for the cotton whitefly.

The number of days required for the B-biotype of B. tabaci to complete development from egg to adult was very similar in the host preference study (greenhouse assay at average $22^{\circ} \mathrm{C}$ ) and in the development study (climatic chamber at constant $26^{\circ} \mathrm{C}$ ) possibly because the greenhouse temperature was nearly $28^{\circ} \mathrm{C}$ at noon.

Although C. album has been mentioned as a weed host of the cotton whitefly in Egypt (Azab et al., 1970), our results show that C. album, E. crus-galli and $A$. retroflexus were not suitable hosts for both Band Q-biotypes of B. tabaci. Brown et al. (1996) hypothesized that if a particular population is capable of colonizing and/or feeding on a particular host, then that host may be an important link in disease epidemiology. Weed species hosting whiteflies may play important roles as virus reservoirs. For example, $S$. $n i$ grum, a very common European weed, can be infected by the tomato yellow leaf curl virus (Bedford et al., 1998). Granillo et al. (1974) reported the isolation of a mosaic virus from Hibiscus cannabinus that was transmissible by $B$. tabaci to $D$. stramonium. Recognition and control of weeds that can host pests and disease organisms may prevent outbreaks (Yassin \& Bendixen, 1982).
As weeds are important reservoirs for whiteflies they could offer a continuum of year-round, susceptible host material and the opportunity for these insects to move within and among cropping systems expanding their populations (Chu et al., 1995). Therefore, estimating biological parameters, such as the infestation and developmental rates on these plants, and a precise regional whitefly management programme is needed to decrease their overall impact (Watson et al., 1992), as well as a better understanding of the influence of whitefly reproduction on crop production

Among the winter weeds tested in this study, the best host in terms of fecundity, fertility, adult emergence and adult survival from egg to adult was $M$. parviflora, B. kaber and C. bursa-pastoris were intermediate hosts. If the overwintering population of $B$. tabaci decreases in a given area, where the aforementioned plants are present, relative numbers on susceptible crops will significantly decrease in the subsequent season, thus having a positive effect on crop production in that area. For summer weeds, the findings of this study strongly suggest that control of $D$. stramonium and $S$. nigrum is recommended to avoid the risk of $B$. tabaci infesting horticultural crops where its presence is a major problem. These results bear out the idea that numbers of the Q-biotype may be increasing in southern Spain as, in general, that biotype presented a greater reproductive capacity, greater infestation potential and shorter development times than the B-biotype.

\section{Acknowledgements}

This study was funded by the Spanish Ministry of Education and Culture. CICYT, Project reference AGF 95-0253-C02-01. I am grateful to Dr F. Beitia (INIA, 
Spain) for supplying whiteflies and to Dr G. Nombela (CSIC, Spain) for her critical reading of the manuscript.

\section{References}

Avidov, Z., 1956. Bionomics of the tobacco whitefly (Bemisia tabaci Gennadius) in Israel. Israel Ktavm 7: 25-41.

Azab, A. K., M. M. Megahed \& H. D. El-Mirsawe, 1970. On the range of host-plants of Bemisia tabaci (Genn.) (HomopteraAleyrodidae). Bulletin of the Society of Entomology of Egypt 54: 319-326.

Bedford, I. D., R. W. Briddon, P. Jones, N. Alkaff \& P. G. Markham, 1994a. Differentiation of three whitefly-transmitted geminiviruses from the republic of Yemen. European Journal of Plant Pathology 100: 243-257.

Bedford, I. D., M. Pinner, S. Liu \& P. G. Markham, 1994b. Bemisia tabaci potential infestation, phytotoxicity and virus transmission within European Agriculture. Proceedings of the Brighton Crop Protection Conference: Pests and Diseases 3. The British Crop Protection Council, Farnham, UK., pp. 911-916

Bedford, I. D., A. Kelly, G. K. Banks, R. W. Briddon, J. L. Cenis \& P. G. Markham, 1998. Solanum nigrum: An indigenous weed reservoir for a tomato yellow leaf curl geminivirus in Southern Spain. European Journal of Plant Pathology 104: 221-222.

Bellows, T. S. (Jr.), T. M. Perring, R. J. Gill \& D. H. Headrick, 1994. Description of a species of Bemisia (Homoptera: Aleyrodidae). Annals of the Entomological Society of America 87: 195-206.

Bernays, E. A. \& R. F. Chapman (eds.), 1994. Host-Plant Selection by Phytophagous Insects. Chapman \& Hall. London. 312 pp.

Bethke, J. A., T. D. Paine \& G. S. Nuessly, 1991. Comparative biology, morphometrics, and development of two populations of Bemisia tabaci (Homoptera:Aleyrodidae) on cotton and poinsettia. Annals of the Entomological Society of America 84: 407-411.

Bird, J. \& K. Maramorosh, 1978. Viruses and virus diseases associated with whiteflies. Advances in Virus Research 22: 55-110.

Brown, J. K., 1990. An update on the whitefly-transmitted geminiviruses in The Americas and the Caribbean basin. FAO Plant Protection Bulletin 39: 5-23.

Brown, J. K., 1994. Current status of Bemisia tabaci as a plant pest and virus vector in agroecosystems world-wide. FAO Plant Protection Bulletin 42: 3-32.

Brown, J. K. \& J. Bird, 1992. Whitefly-transmitted geminiviruses and associated disorders in the Americas and the Caribbean Basin. Plant Disease 76: 220-25.

Brown, J. K \& J. Bird, 1996. Introduction of an exotic whitefly (Bemisia) vector facilitates secondary spread of jatropha mosaic virus, a geminivirus previously vectored exclusively by the 'jatropha' biotype. In: D. Gerling \& R. T. Mayer (eds), Bemisia 1995: Taxonomy, Biology, Damage, Control and Management. Intercept, Andover, U.K., pp. 351-353.

Brown, J. K., J. Bird, D. R. Frohlich, R. C. Rosel, I. D. Bedford \& P. G. Markham, 1996. The relevance of variability within the $B e$ misia tabaci species complex to epidemics caused by subgroup III geminiviruses. In: D. Gerling \& R. T. Mayer (eds), Bemisia 1995: Taxonomy, Biology, Damage, Control and Management. Intercept, Andover, U.K., pp. 77-89.

Byrne, D. N. \& E. A. Draeger, 1989. Effect of plant maturity on oviposition and nymphal mortality of Bemisia tabaci (Homoptera: Aleyrodidae). Environmental Entomology 18: 429-432
Byrne, D. N., T. S. , T. S. Bellows (Jr.) \& M. P. Parrela, 1990. Whiteflies in agricultural systems. In: D. Gerling (ed.), Whiteflies: Their Bionomics, Pest Status and Management. Intercept, Andover, U.K., pp. 227-261.

Calvetti, M. \& P. C. Remotti, 1998. Host preference and performance of Bemisia argentifolii (Homoptera: Aleyrodidae) on weeds in Central Italy. Environmental Entomology 27: 13501356.

Carnero, A., M. Montesdeoca, F. Pérez, A. Silverio \& P. Rodríguez, 1990. Presencia de Bemisia tabaci (Genn.) en cultivos comerciales de hortícolas y ornamentales en la isla de Tenerife (Islas Canarias). Cuadernos de Fitopatología, $4^{\circ}$ Trimestre 25: 176-180.

Chu, C-C., T. J. Henneberry \& A. C. Cohen, 1995. Bemisia argentifolii (Homoptera: Aleyrodidae): Host preference and factors affecting oviposition and feeding site preference. Environmental Entomology 24: 354-360.

Coudriet, D. L., D. E. Meyerdirk, N. Prabhaker \& A. N. Kishaba, 1986. Bionomics of sweetpotato whitefly (Homoptera: Aleyrodidae) on weeds hosts in the Imperial Valley, California. Environmental Entomology 15: 1179-1183.

Drost, Y. C., J. C. van Lenteren \& H. J. W. van Roermund, 1998 Life-history parameters of Bemisia tabaci (Hemiptera: Aleyrodidae) in relation to temperature and host plant: a selective review. Bulletin of Entomological Research 88: 219-229.

Fattah, M. I. A., A. Hindi \& A. El Said, 1984. Abundance of Bemisia tabaci (Genn.) associated with common weed in tomato fields at Shebin El-Kom region, Egypt (Homoptera: Aleyrodidae). Bulletin of the Society of Entomology of Egypt 65: 109-117.

Gameel, O. I., 1972. A new description, distribution and hosts of the cotton whitefly (Bemisia tabaci Genn.). Review of Zoology and Botany of Africa 86: 50-64.

Gerling D., 1967. Bionomics of the whitefly-parasite complex associated with cotton in Southern California (Homoptera: Aleyrodidae; Hymenoptera: Aphelinidae). Annals of the Entomological Society of America 60: 1306-1321.

Gerling, D., 1983. Overwintering of Bemisia tabaci in Israel. Phytoparasitica 11: 65.

Gerling, D., 1984. The overwintering mode of Bemisia tabaci and its parasitoids in Israel. Phytoparasitica 12: 109-118.

Gómez-Menor, J., 1943. Contribución al conocimiento de los Aleyródidos de España. (Hem. Homoptera). $1^{\mathrm{a}}$ notas. Eos 19: 173-209.

Granillo, C. R., A. Díaz \& M. Anaya, 1974. The mosaic virus of kenaf (Hibiscus cannabinus) in El Salvador. Phytopathology 64: 768.

Guirao, P., F. Beitia \& J. L. Cenis, 1997. Biotype determination of Spanish populations of Bemisia tabaci (Hemiptera: Aleyrodidae). Bulletin of Entomological Research 87: 587-593.

Hågvar, E. B. \& T. Hofsvang, 1991. Aphid parasitoids (Hymenoptera, Aphididae): biology, host selection and use in biological control. Biocontrol News Inf. 12: 13-41.

Leather, S. R., K. F. A. Walters \& J. S. Bale (eds), 1993. The Ecology of Insect Overwintering. Cambridge University press, $255 \mathrm{pp}$.

Markham, P. G., I. D. Bedford, S. Liu \& M. S. Pinner, 1994. The transmission of geminiviruses by Bemisia tabaci (Gennadius). Pesticide Science 42: 123-128.

Moriones, E., J. Arnó, G. P. Accotto, E. Noris \& L. Cavallarin, 1993. First report of Tomato yellow leaf curl virus in Spain. Plant Disease 77: 953.

Muñiz, M. \& G. Nombela, 1997a. Development, oviposition and female longevity of two biotypes of Bemisia tabaci (Homoptera: 
Aleyrodidae) on three varieties of Capsicum annuиm L. IOBC/ WPRS Bulletin 20: 143-146.

Muñiz, M. \& G. Nombela, 1997b. Host preference, pupal production and sex ratio of Bemisia tabaci (Homoptera: Aleyrodidae) on three varieties of Capsicum annuum L.. In: A. Hanafi (ed.), Proceedings of the International Symposium on Integrated Production and Protection in Horticultural Crops. Agadir (Morocco), pp. 473-479

Ozgur, A. F., E. Sekeroglu, B. Ohnesorge \& H. Gocmen, 1989. Studies on the population dynamics of Bemisia tabaci Genn. (Homoptera: Aleyrodidae) in Cucurova, Turkey. Journal of Applied Entomology 107: 217-227.

Perring, T. M., A. D. Cooper, R. J. Rodríguez, C. A. Farrar \& T. S. Bellows (Jr.), 1993. Identification of a whitefly species by genomic and behavioural studies. Science 259: 74-77.

Rossell, R. C., I. D. Bedford, D. R. Frohlich, R. J. Gill, J. K. Brown \& P. G. Markham, 1997. Analysis of morphological variation in distinct populations of Bemisia tabaci (Homoptera: Aleyrodidae). Annals of the Entomological Society of America 90: 575-589.
StatSoft, 1994. Statistica version 4.5 for the Windows operating system. Reference for statistical procedures. StaSoft, Tulsa, OK. Villarias, J. L., 1979. Atlas de Malas Hierbas. Ediciones MundiPrensa. Madrid, Spain, $301 \mathrm{pp.}$

Wang, K. \& J. H. Tsai, 1996. Temperature effect on development and reproduction of silverleaf whitefly (Homoptera: Aleyrodidae). Annals of the Entomological Society of America 89: 375-384.

Watson, T. F., J. C. Silvertooth, A. Teller \& L. Lastra, 1992. Seasonal dynamics of sweetpotato whitefly in Arizona. Southwest Entomology 17: 149-167.

Yassin, M. \& L. E. Bendixen, 1982. Weed hosts of the cotton whitefly Bemisia tabaci (Genn.) (Homoptera: Aleyrodidae) Ohio Agricultural Research and Development Center, Research Bulletin 1114: 1-10.

Zalom, F. G., C. Castañé \& R. Gabarra, 1995. Selection of some winter-spring vegetable crop hosts by silverleaf whitefly. Journal of Economic Entomology 88: 70-76. 